\title{
Effects of site, silviculture and seedlot on wood density and estimated wood stiffness in radiata pine at mid-rotation
}

\author{
Sue D Carson ${ }^{1}$, Dave J Cown ${ }^{2}$, Russell B McKinley ${ }^{2}$ and John R Moore ${ }^{2^{*}}$
}

\begin{abstract}
Background: To understand the underlying control of patterns of important wood properties is fundamental to silvicultural control of wood quality and genetic selection. This study examines the influences of site, silviculture and seedlot on diameter growth, wood density and estimated wood stiffness in mid-rotation radiata pine (Pinus radiata D Don) stands across New Zealand.

Methods: Selected treatment combinations were assessed across five sites in a 17-year-old experiment comparing silvicultural treatments and improved breeds of radiata pine. Diameter at breast height (DBH), and stress-wave velocity (an indicator of wood stiffness) and outerwood (outermost five growth rings) basic density at breast-height were assessed for ten trees from each plot in the experiment.

Results: There were large differences in DBH and wood properties between sites. Silviculture (stand density) had a stronger influence than seedlot on DBH and stress-wave velocity, while the converse applied to outerwood density. There was a positive relationship between stand density and both stress-wave velocity and outerwood density. Trees in the un-pruned 500 stems ha ${ }^{-1}$ treatment had larger DBH, lower outerwood density and lower stress-wave velocity than trees in the 400 stems ha ${ }^{-1}$ pruned treatment. This suggests that silvicultural manipulation (pruning) of green crown length is important for controlling both growth and wood properties.

Conclusions: Results from this study support previous research which indicates that thinning, and to a lesser extent pruning, have a strong impact on DBH, stress-wave velocity and outerwood density. Increasing stand density is consistently associated with stiffer and denser outerwood.
\end{abstract}

Keywords: Pinus radiata; Silviculture; Site; Genotypes; Wood density; Stress-wave velocity

\section{Background}

Variation in wood characteristics within and between trees is affected by a number of factors including tree age (cambial ageing), environment (site and climate) and genetics (Downes and Drew 2008; Larson 1969; Zobel and Sprague 1998). Some of these factors, such as the choice of genetic material and tree spacing, can be manipulated by silviculturalists to achieve desired woodquality outcomes. Understanding environmental impacts on wood quality is also important, so that silvicultural regimes targeting particular end products can be developed for different sites. Several studies have documented

\footnotetext{
* Correspondence: john.moore@scionresearch.com

${ }^{2}$ Scion, Private Bag 3020, Rotorua, New Zealand

Full list of author information is available at the end of the article
}

the influence of site and climatic conditions on the growth and wood properties of radiata pine (Pinus radiata D. Don) (e.g. Cown et al. 1991; Palmer et al. 2013), which is the major commercial forestry species in New Zealand (Ministry for Primary Industries 2013). Maps representing spatial variation in wood density of radiata pine in New Zealand have been developed, classifying the country into distinct zones (Cown et al. 1991; Palmer et al. 2013), primarily related to mean annual temperature.

The effects of silviculture and genetics on wood properties, particularly density, are often assumed to be a consequence of their impacts on radial growth rates. In radiata pine, as in many other softwood species, there is an adverse correlation between tree growth rate and wood density (Burdon and Harris 1973). Trees grown at

\section{实}

(C) 2014 Carson et al.; licensee Springer. This is an Open Access article distributed under the terms of the Creative Commons Attribution License (http://creativecommons.org/licenses/by/4.0), which permits unrestricted use, distribution, and reproduction in any medium, provided the original work is properly credited. 
wider spacing generally have lower wood density compared with those grown at closer spacing (Cown 1974) while differences have also been observed in other properties such as modulus of elasticity and microfibril angle (Lasserre et al. 2009; Watt et al. 2011). Wood-quality variation in radiata pine has been less studied from a genetic aspect, but most properties have been shown to be both highly variable and highly heritable (Apiolaza et al. 2013; Kumar and Burdon 2010). From a forestmanagement perspective, the combination of using faster growing genetically improved stock and the move to shorter rotation lengths, has placed emphasis on the resultant quality of the central core of juvenile wood (Burdon et al. 2004; Cown 1992; Lasserre et al. 2009) as the trees grown under these conditions will have a higher proportion of juvenile wood.

Much of the earlier research into wood-property variation in radiata pine, and other species, focused on density due its relative ease of measurement and correlation with other wood properties (Cown et al. 2002). However, modulus of elasticity is an important wood property that affects the performance of timber in structural applications. It is related to both density and microfibril angle, and can be estimated using stresswave non-destructive techniques (Ross and Pellerin 1988). Recent advances in portable acoustic tools have provided the ability to investigate variation of estimated wood stiffness (modulus of elasticity) in standing trees and logs (Wang 2013; Wang et al. 2001). While standing-tree velocity measurements are not as well correlated with the stiffness of the resulting sawn timber as resonance measurements made on logs (Wang 2013), they can be applied to young trees, which permit more rapid assessment of the combined effects of silviculture and genetics early in the life of a stand. For example, Lasserre et al. (2005) found that both stand density and genotype significantly influenced the estimated stiffness of 11-year-old radiata pine clones established at initial stand densities

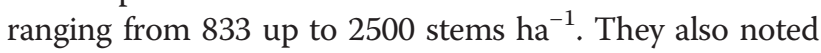
a positive correlation between stiffness and stand density, independent of genotype. Conversely, in a 27-year-old radiata pine experiment established at 625 stems ha $^{-1}$, which had some plots thinned to 100 stems ha $^{-1}$ at mid-rotation, Grabianowski et al. (2004) found large tree-to-tree differences in estimated wood stiffness but no significant effect of stand density, despite a large contrast in stem diameter.

The interactions of the various influences on wood formation and properties remain an important aspect of radiata pine forestry. In particular, understanding the underlying control of patterns of important wood properties is fundamental to silvicultural control of wood quality. Using data from a national series of experiments, the main objective of the present study was to quantify site, silvicultural and seedlot (genetic) influences on diameter growth, wood density and estimated wood stiffness in mid-rotation radiata pine stands across New Zealand.

\section{Methods}

\section{Experimental design}

The study was based on a subset of sites and treatment combinations from a series of experiments that were established in 1987 to investigate the interaction of silviculture and genetics on growth of radiata pine. The design of these experiments is described in more detail by Carson et al. (1999b), who also presented some preliminary analysis results showing the relative effects of site, silviculture and genetics on stand basal area, height, and volume at age eight years (i.e. at approximately one-third rotation). These early analyses showed large site-level differences in height, basal area and volume compared with seedlot differences. In this study, five installations (sites) of the experiment were sampled that covered a range of climatic and soil conditions, and had contrasting site indices (Table 1; Figure 1). Three of these installations (Woodhill, Kaingaroa, Tahorakuri) were established on former forest sites, while the other two (Glengarry, Otago Coast) were established on ex-farm sites. At each of these installations, three silvicultural

Table 1 Characteristics of the sites from the 1987 silviculture-breeds experiments sampled in this study

\begin{tabular}{|c|c|c|c|c|c|c|c|c|c|c|}
\hline Forest & Latitude & $\begin{array}{l}\text { Mean annual } \\
\text { rainfall }(\mathrm{mm})\end{array}$ & $\begin{array}{l}\text { Mean } \\
\text { temperature }{ }^{1} \\
\left({ }^{\circ} \mathrm{C}\right) \text { (range) }\end{array}$ & $\begin{array}{l}\text { Elevation } \\
\text { (m a.s.I.) }\end{array}$ & $\begin{array}{l}\text { Mean wind } \\
\text { speed }^{1}(\mathrm{~km} / \mathrm{h})\end{array}$ & $\begin{array}{l}\text { Mean solar } \\
\text { radiation }{ }^{2} \\
\left(\mathrm{MJ} / \mathrm{m}^{2}\right)\end{array}$ & $\begin{array}{l}\text { Mean relative } \\
\text { humidity }^{2}(\%)\end{array}$ & $\begin{array}{l}\text { Previous } \\
\text { land use }\end{array}$ & $\begin{array}{l}\text { Site } \\
\text { index }\end{array}$ & $\begin{array}{l}\text { Age at } \\
\text { thinning } \\
\text { (years) }\end{array}$ \\
\hline Woodhill & $36^{\circ} 30^{\prime}$ & 1495 & $14.0(18-10)$ & 80 & 8.7 & 13.8 & 84.3 & Forest & Medium & 5.6 \\
\hline Tahorakuri & $38^{\circ} 20^{\prime}$ & 1254 & $12.0(17-7)$ & 450 & 7.0 & 13.4 & 84.7 & Forest & Medium & 4.9 \\
\hline Kaingaroa & $39^{\circ} 10^{\prime}$ & 1618 & $10.2(15-5)$ & 750 & 7.0 & 13.4 & 84.8 & Forest & Low & 6.8 \\
\hline Glengarry & $41^{\circ} 30^{\prime}$ & 1515 & $12.7(17-8)$ & 500 & 10.5 & 13.5 & 72.8 & Farm & High & 4.8 \\
\hline Otago coast & $46^{\circ} 00^{\prime}$ & 781 & $10.0(14-6)$ & 150 & 14.4 & 11.0 & 79.3 & Farm & High & 6.9 \\
\hline
\end{tabular}

${ }^{1}$ Mean of monthly averages.

${ }^{2}$ Mean of daily averages.

${ }^{3}$ Former farm sites have higher fertility than forest sites.

${ }^{4}$ Relative to sites in the same region. 


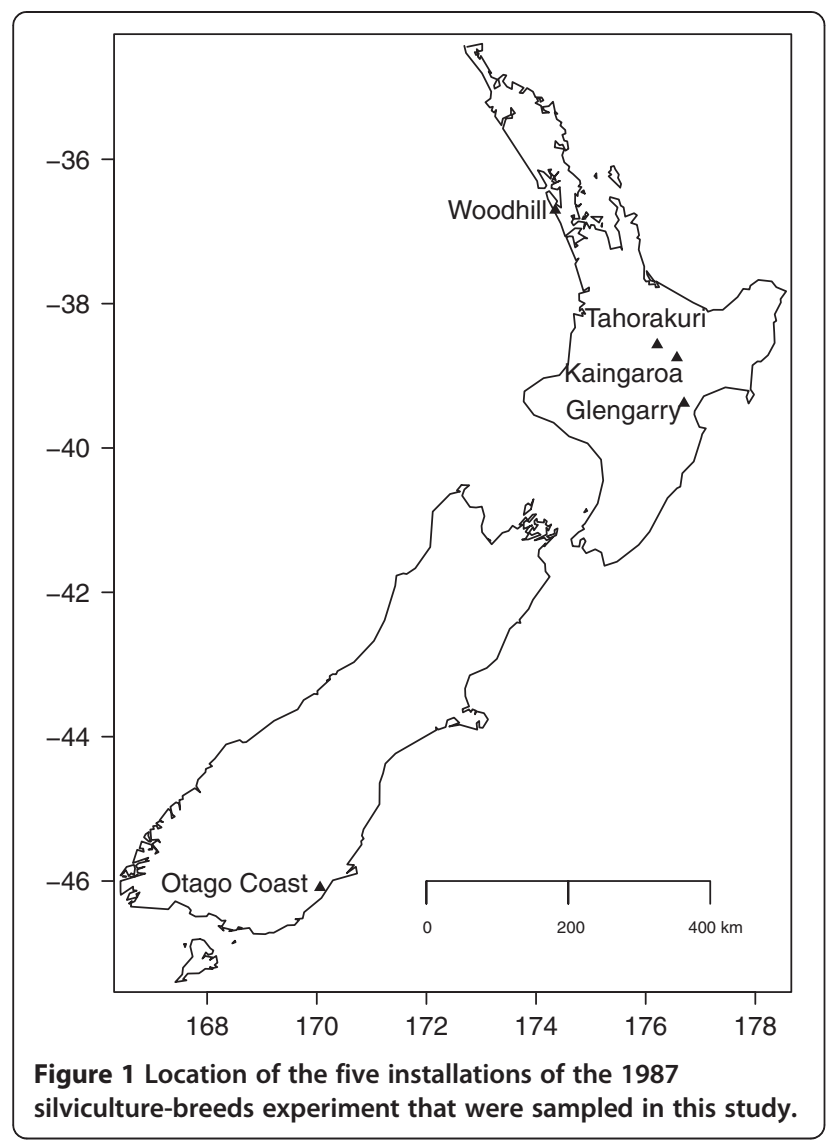

treatments were sampled (Table 2), in combination with three seedlots, representing high growth rate, stem straightness and a range of branching habits (Table 3).

The three seedlots that were genetically improved for growth rate and stem form had not undergone direct selection for wood properties, so were not expected to differ greatly from one another for wood properties. However, selection for improved growth rate may have indirectly and unconsciously 'selected' for reduced wood density in these seedlots when compared to unimproved seedlots, due to the negative genetic correlation between wood density and diameter growth rate (Burdon 2010). Seedlot 1 was rated by the New Zealand Seed Certification Service as GF14 (Jayawickrama and Carson
2000), seedlot 2 was rated as GF21. The GF rating system was developed to enable genetic quality of alternative seedlots to be differentiated, and was based on a onethird weighting for stem form and a two-thirds weighting for growth rate, where a higher number reflects a higher level of genetic improvement. The GF14 seedlot contained seed collected from an open-pollinated clonal seed orchard, whereas the GF21 seedlot was produced by controlled-pollination among several seed orchard parents. Seedlot 3 was rated as GF13, and was the result of controlled pollination among parents selected primarily for exceptionally long internodes as well as increased growth. This third seedlot represents a 'long internode' breed and is also given a long internode (LI) rating of LI28. Ratings of genetic worth reported in Table 3 also include the more recently derived GF Plus ratings for the seedlots used in this study. As distinct from the GF ratings, GF Plus ratings are allocated by individual trait, but they are similar with respect to the convention that higher values represent greater genetic improvement.

Plots within the experiment were established at stand densities ranging from 250 to 1000 stems ha $^{-1}$. However, at three of the sites (Woodhill, Tahorakuri and Glengarry) the most widely spaced treatments were established at 500 stems $\mathrm{ha}^{-1}$. Plot sizes ranged from 0.081 ha up to 0.324 ha (including buffers) with the inner plot sizes (that included the measurement trees) ranging in size from 0.049 ha up to 0.196 ha (Table 2). When the mean tree height reached $6.2 \mathrm{~m}$, plots were thinned to stand densities ranging from 100 to 400 stems ha $^{-1}$. This gave a ratio of pre- to postthinning stand density of 5:2. Trees were also pruned at this time to leave approximately $4 \mathrm{~m}$ of green crown remaining. This corresponded to a pruned height of approximately $2.2 \mathrm{~m}$; typically radiata pine is pruned to a height of $6 \mathrm{~m}$ in three lifts, so the intensity of pruning in this experiment is less than would occur in practice. In one treatment (500 stems $\mathrm{ha}^{-1}$ ), plots were not thinned or pruned and were left at their initial stand density of 500 stems $\mathrm{ha}^{-1}$. Each treatment combination was replicated twice at each site. One replicate from four treatment combinations could not be sampled (GF13 and GF14 100 stems ha ${ }^{-1}$ at Otago Coast, GF14 400 and 500 stems ha $^{-1}$ at Tahorakuri), so that a total of 86 plots were sampled.

Table 2 Silvicultural treatments in the 1987 silviculture-breeds experiments

\begin{tabular}{lllllll}
\hline Treatment & \multicolumn{2}{l}{ Stand density (stems $\mathbf{h a}^{\mathbf{- 1}}$ ) } & Crown remaining after pruning (m) & Outer plot size (ha) & Inner plot size (ha) & No. of trees $^{\mathbf{3}}$ \\
\cline { 2 - 7 } & Initial & Post-thinning & & & \\
\hline 1 & 250 or $500^{1}$ & 100 & 4 & 0.324 & 0.196 & 98 \\
2 & 1000 & 400 & 4 & 0.081 & 0.049 & 49 \\
3 & 500 & 500 & No pruning & 0.162 & 0.098 & 49 \\
\hline
\end{tabular}

${ }^{1}$ Initial stand density was 500 stems ha $^{-1}$ at Woodhill, Tahorakuri and Glengarry.

${ }^{2}$ Thinning was carried out at a mean stand height of approximately $6.2 \mathrm{~m}$.

${ }^{3}$ Number of trees in inner permanent sample plot before thinning. 
Table 3 Descriptions of the seedlots in the 1987 silviculture-breeds experiment that were assessed in this study

\begin{tabular}{llllll}
\hline Seedlot & Breed & GF rating & & GFPlus ratings ${ }^{\mathbf{1}}$ & \\
\cline { 5 - 6 } & & & Diameter & Stem form & Branching \\
\hline $3 / 3 / 85 / 01$ & Multinodal & GF14 & 17.5 & 19 & 21 \\
$6 / 3 / 86 / 46$ & Multinodal & GF21 & 21.2 & 21 & 23 \\
$9 / 3 / 86 / 166$ & Long Internode & LI28 (GF13) & 17.7 & 18 & 1 \\
\hline
\end{tabular}

${ }^{1}$ GF Plus ratings are assigned by the Radiata Pine Breeding Company based on breeding values for traits of interest.

\section{Growth and wood properties assessment}

At age 17 years after planting (i.e. approximately half to two-thirds of the typical rotation length for radiata pine in New Zealand), ten trees were selected at random from each treatment plot and their diameter at breast height $(\mathrm{DBH})$ measured. Stress-wave velocity measurements were made on each tree using the IML Hammer (Instrumenta Mechanic Labor GmbH, Germany). Two sets of measurements were made on the north and south sides of each tree. These measurements were centred about breast height $(1.4 \mathrm{~m})$ and the probes of the instrument were spaced approximately $1 \mathrm{~m}$ apart along the longitudinal axis of the stem. These two measurements were averaged to give a single value for each tree. An outerwood increment core (5 $\mathrm{mm}$ in diameter) was collected at breast height from each tree. This core contained the five outermost annual rings (approximately $50 \mathrm{~mm}$ in length) and is the standard density sample collected from standing trees in New Zealand (Cown and McConchie 1983). For trees with any obvious lean, cores were collected on the upper stem-side in order to avoid compression wood. In some plots it was not possible to collect cores from all ten trees and, therefore, a total of 854 of core samples were collected. All individual outerwood segments were assessed for basic density $\left(\mathrm{kg} \mathrm{m}^{-3}\right)$ using the maximum moisture content method (Smith 1954) without resin extraction.

\section{Data analysis}

Average values by site, silviculture, and seedlot were calculated for all measured traits. A variance-components analysis was conducted to determine how much variation was associated with each stratum in the experiment, i.e. site, replicate within site, plot within replicate and tree within plot. Analyses of variance were then used to examine the differences in trait expression assuming a randomised complete block structure. For each trait, analyses were carried out for all sites following the same approach described in Carson et al. (1999b). Sources of variation included main effects of site, replication within site, silviculture, and seedlot. Interaction effects of site by silviculture, site by seedlot, silviculture by seedlot, and the three-way interaction were also included. Site and replication within site were treated as random effects, while seedlot and silviculture were treated as fixed effects. Seedlot was tested against the site by seedlot interaction, and silviculture against the site by silviculture interaction. Analyses of growth traits were based on all trees in a treatment, rather than just the sample selected for wood properties assessment. For the 100 and 400 stems ha $^{-1}$ treatments, approximately 20 trees were assessed for growth, while approximately 49 were assessed in the 500 stems $\mathrm{ha}^{-1}$ treatment. Simple correlation analysis was also used to test for potential relationships between outerwood density and stress-wave velocity, and between radial growth rate and both outerwood density and stress-wave velocity.

\section{Results}

The greatest single source of variation in outwerwood density and stress-wave velocity was differences among individual trees within a plot, followed by differences among sites (Table 4). Differences among treatments accounted for 13.4 and $26.1 \%$ of the variation in outerwood density and stress-wave velocity, respectively. The greatest source of variation in $\mathrm{DBH}$ was the difference among treatment plots, followed by the difference among trees within a plot and then site. At each of the five individual sites, there was more variation in $\mathrm{DBH}$ and stress-wave velocity among silvicultural treatments than among seedlots, while the converse situation was observed for outerwood density (Figure 2).

\section{Site-level differences}

The five sites assessed represented a range of performance for growth and wood properties (Table 5). Site mean DBH and outerwood density showed a relatively large range, from 366 (Kaingaroa) to $475 \mathrm{~mm}$ (Glengarry) for $\mathrm{DBH}$

Table 4 Percentage of total variation in DBH, stress-wave velocity and breast height outerwood density attributable to each stratum in the experiment

\begin{tabular}{llll}
\hline Stratum & \multicolumn{3}{l}{$\begin{array}{l}\text { Percentage of variation attributable } \\
\text { to each stratum }\end{array}$} \\
\cline { 2 - 4 } & DBH & $\begin{array}{l}\text { Stress-wave } \\
\text { velocity }\end{array}$ & $\begin{array}{l}\text { Outerwood } \\
\text { density }\end{array}$ \\
\hline Site & 27.1 & 32.9 & 41.4 \\
Rep within site & 0.00 & 0.00 & 0.00 \\
Plot within rep & 44.9 & 26.1 & 13.4 \\
Tree within plot & 28.0 & 41.0 & 45.2 \\
\hline
\end{tabular}




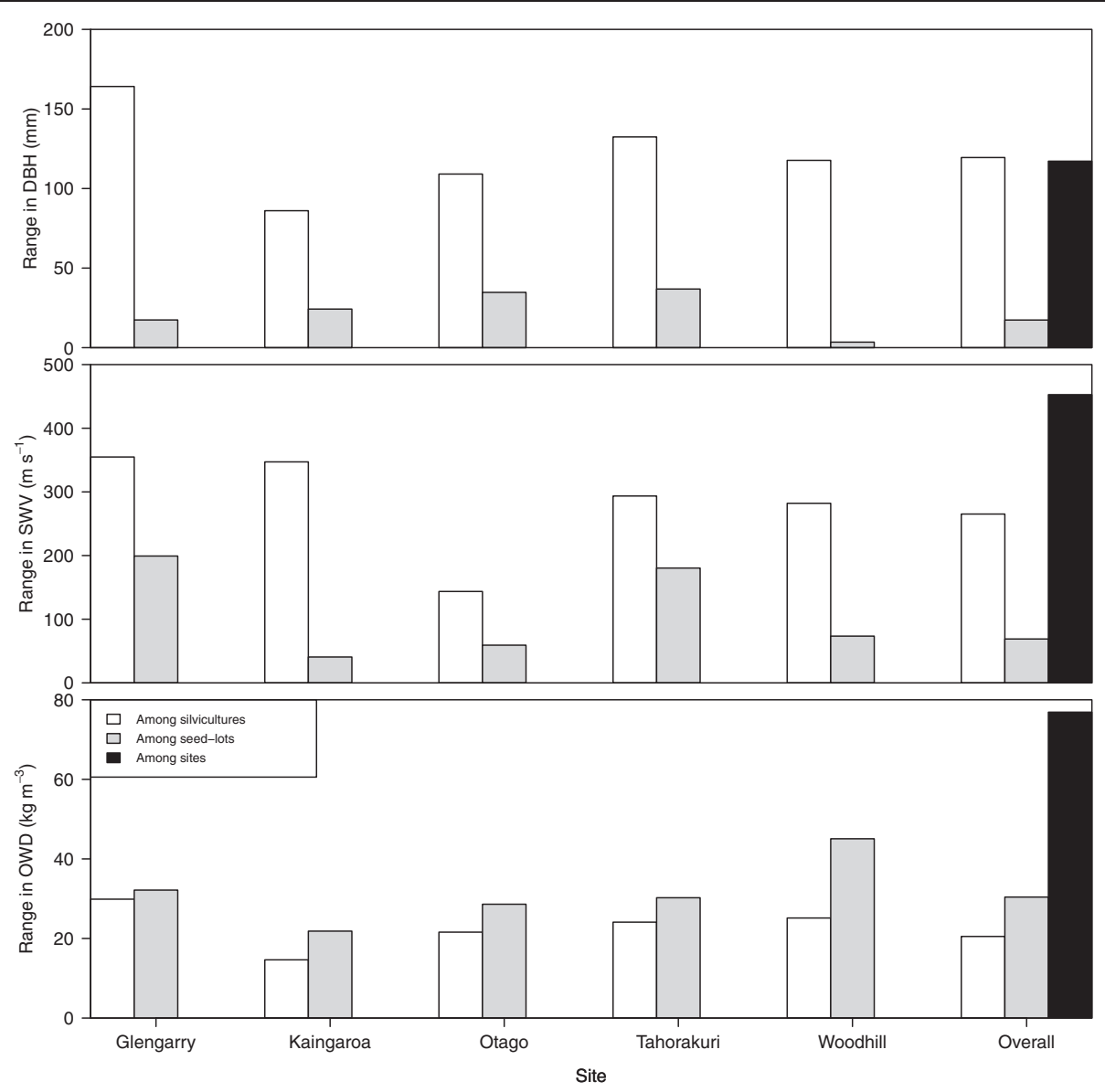

Figure 2 Range of treatment-level average values of DBH, stress-wave velocity (SWV) and outerwood density (OWD) at each of the five sites. The overall range across the five sites is also given.

and 375 (Kaingaroa) to $451 \mathrm{~kg} \mathrm{~m}^{-3}$ (Woodhill) for outerwood density. Outerwood density values showed a strong regional trend with increasing latitude (and elevation). Site mean stress-wave velocity ranged from $2035 \mathrm{~m} \mathrm{~s}^{-1}$ (Otago Coast) to $2487 \mathrm{~m} \mathrm{~s}^{-1}$ (Woodhill). Site differences were highly significant for all traits assessed (Table 6).

\section{Differences among silvicultural treatments}

In the thinned treatments there was a clear trend of decreasing DBH with increasing stand density (Table 5; Figure 3). However, the un-pruned, un-thinned 500 stems ha ${ }^{-1}$ treatment did not adhere to this trend. Overall they had the same mean DBH as the 400 stems ha ${ }^{-1}$ treatment, although differences were observed at some sites, i.e. Glengarry, Kaingaroa and Tahorakuri (Figure 3). Stress wave velocity increased as stand density increased from 100 stems ha $^{-1}$ up to 400 stems ha ${ }^{-1}$ (Table 5). Again, the un-pruned, un-thinned 500 stems ha $^{-1}$ treatment did not appear to adhere to this trend, yielding on average a slightly lower velocity even than for the 100 stems $\mathrm{ha}^{-1}$ treatment. This trend was consistent across each of the five sites (Figure 3). Outerwood density was also significantly different among silvicultural treatments, but the effect was not as strong as for DBH (Table 6). In the treatments that had been thinned, there was a trend at all sites for higher stocked stands to have higher densities in the outerwood but not for the un-thinned controls (Figure 3).

\section{Differences among seedlots}

There were small differences in DBH among seedlots with GF13 (LI28) trees having a smaller mean diameter than those from the G14 and GF21 seedlots (Table 5). There was a significant site $\times$ seedlot interaction on DBH (Table 6). Stress-wave velocity also differed among seedlots. Across all sites and silvicultural regimes the GF21 seedlot had the highest average stress-wave velocity $\left(2288 \mathrm{~m} \mathrm{~s}^{-1}\right)$ and the GF14 seedlot the lowest $\left(2221 \mathrm{~m} \mathrm{~s}^{-1}\right)$. There was a small site $\times$ seedlot interaction, with GF13 having the highest stress-wave velocity at the Kaingaroa and Tahorakuri sites (Figure 4). Outerwood density also differed significantly between seedlots (Tables 5 and 6). The long internode (LI28) GF13 seedlot consistently had the highest outerwood density on all sites, and the GF14 


\section{Table 5 Values of diameter at breast height, breast height outerwood density and stress-wave velocity by site, seedlot and silvicultural regime}

\begin{tabular}{|c|c|c|c|c|c|c|c|c|c|c|c|c|c|c|c|c|c|c|c|c|}
\hline \multirow{3}{*}{$\begin{array}{l}\text { Stand } \\
\text { density } \\
\text { (stems ha }^{-1} \text { ) }\end{array}$} & \multicolumn{20}{|c|}{ Seedlot and site } \\
\hline & \multicolumn{4}{|l|}{ Woodhill } & \multicolumn{4}{|l|}{ Kaingaroa } & \multicolumn{4}{|c|}{ Tahorakuri } & \multicolumn{4}{|l|}{ Glengarry } & \multicolumn{4}{|c|}{ Otago coast } \\
\hline & GF13 & GF14 & GF21 & Mean & GF13 & GF14 & GF21 & Mean & GF13 & GF14 & GF21 & Mean & GF13 & GF14 & GF21 & Mean & GF13 & GF14 & GF21 & Mean \\
\hline \multicolumn{21}{|l|}{$D B H(m m)$} \\
\hline 100 & $484(476)$ & $460(441)$ & $458(443)$ & $467(455)$ & $420(407)$ & $442(437)$ & $434(424)$ & $432(423)$ & $509(508)$ & $529(532)$ & $507(487)$ & $520(509)$ & $586(577)$ & $621(597)$ & $600(596)$ & $602(590)$ & $473(474)$ & $558(541)$ & $512(499)$ & $496(50$ \\
\hline 400 & $335(334)$ & $347(346)$ & $349(350)$ & $343(345)$ & $324(326)$ & $335(341)$ & $346(343)$ & $335(337)$ & $369(362)$ & $395(385)$ & $383(386)$ & $382(378)$ & $403(419)$ & $435(441)$ & $412(416)$ & $398(426)$ & $403(405)$ & $398(388)$ & $398(404)$ & $400(399)$ \\
\hline 500 & $354(323)$ & $355(352)$ & $337(335)$ & $348(337)$ & $317(335)$ & $345(362)$ & $332(349)$ & $331(348)$ & $389(387)$ & $385(374)$ & $388(423)$ & $387(399)$ & $416(440)$ & $426(450)$ & $432(441)$ & $425(444)$ & $317(382)$ & $398(395)$ & $397(416)$ & $371(39$ \\
\hline Mean & 391 (378) & $387(380)$ & 381 (377) & 386 (378) & $353(356)$ & $374(380)$ & $370(372)$ & $366(369)$ & $424(419)$ & $438(435)$ & $427(432)$ & $430(429)$ & 468 (479) & $476(496)$ & $481(484)$ & $475(487)$ & $391(426)$ & $445(436)$ & $430(440)$ & $422(434)$ \\
\hline \multicolumn{21}{|c|}{ Stress Wave Velocity $\left(\mathrm{km} \mathrm{s}^{-1}\right)$} \\
\hline 100 & 2392 & 2400 & 2376 & 2390 & 2133 & 2042 & 2070 & 2081 & 2180 & 2042 & 2247 & 2156 & 2235 & 2146 & 2399 & 2259 & 2055 & 2027 & 2005 & 2029 \\
\hline 400 & 2581 & 2785 & 2649 & 2672 & 2374 & 2340 & 2357 & 2357 & 2558 & 2375 & 2384 & 2439 & 2609 & 2439 & 2650 & 2566 & 2104 & 2096 & 2129 & 2110 \\
\hline 500 & 2351 & 2372 & 2474 & 2399 & 2006 & 2008 & 2016 & 2010 & 2293 & 2182 & 2231 & 2236 & 2158 & 2170 & 2305 & 2211 & 1945 & 1878 & 2028 & 1967 \\
\hline Mean & 2441 & 2515 & 2504 & 2487 & 2170 & 2130 & 2148 & 2150 & 2343 & 2201 & 2286 & 2277 & 2334 & 2251 & 2450 & 2345 & 2047 & 2005 & 2054 & 2035 \\
\hline \multicolumn{21}{|c|}{ Outerwood Density $\left(\mathrm{kg} \mathrm{m}^{-3}\right)$} \\
\hline 100 & 449 & 436 & 423 & 436 & 382 & 352 & 361 & 365 & 382 & 366 & 376 & 375 & 392 & 350 & 358 & 367 & 394 & 365 & 367 & 375 \\
\hline 400 & 483 & 436 & 464 & 461 & 398 & 364 & 377 & 380 & 419 & 378 & 390 & 395 & 408 & 372 & 409 & 397 & 395 & 381 & 376 & 384 \\
\hline 500 & 492 & 418 & 461 & 457 & 378 & 361 & 385 & 379 & 408 & 381 & 383 & 390 & 394 & 375 & 399 & 389 & 414 & 383 & 380 & 393 \\
\hline Mean & 475 & 430 & 450 & 451 & 386 & 364 & 374 & 375 & 403 & 375 & 382 & 387 & 398 & 366 & 388 & 384 & 401 & 376 & 375 & 384 \\
\hline
\end{tabular}

The values of diameter at breast are given for all trees in the plot as well as those selected for measurement of wood properties (in parentheses). 
Table 6 Analysis of variance results for diameter at breast height, stress wave velocity and outerwood density across all sites

\begin{tabular}{|c|c|c|c|c|c|c|c|}
\hline \multirow[b]{2}{*}{ Source } & \multirow[b]{2}{*}{ df } & \multicolumn{2}{|c|}{ Diameter at breast height } & \multicolumn{2}{|c|}{ Stress wave velocity } & \multicolumn{2}{|c|}{ Outerwood density } \\
\hline & & $F$ & $P>F$ & $\mathrm{~F}$ & $P>F$ & $\mathbf{F}$ & $P>F$ \\
\hline Site & 4 & 66.96 & 0.0002 & 27.62 & 0.0013 & 148.78 & $<0.0001$ \\
\hline Seedlot & 2 & 11.30 & 0.0015 & 4.26 & 0.0219 & 52.70 & $<0.0001$ \\
\hline Silviculture & 2 & 750.88 & $<0.0001$ & 80.84 & $<0.0001$ & 27.32 & $<0.0001$ \\
\hline Site $\times$ Seedlot & 8 & 3.47 & 0.0046 & 2.28 & 0.0435 & 1.99 & 0.0757 \\
\hline Site $\times$ Silviculture & 8 & 15.03 & $<0.0001$ & 2.47 & 0.0304 & 0.98 & 0.4697 \\
\hline Silviculture $\times$ Seedlot & 4 & 2.48 & 0.0608 & 0.55 & 0.7029 & 1.01 & 0.4129 \\
\hline Site $\times$ Silviculture $\times$ Seedlot & 16 & 2.38 & 0.0154 & 0.85 & 0.6245 & 2.20 & 0.0250 \\
\hline
\end{tabular}

seedlot almost always had the lowest (Table 5, Figure 4). There was no evidence of a site $\times$ seedlot interaction for outerwood density, or a silviculture $\times$ seedlot interaction for any of the traits assessed (Table 6).

Inter-relationships between growth and wood quality traits The correlation between wood density in the outer five rings and stress-wave velocity was highly significant $(\mathrm{r}=0.29-0.61$ across individual sites and 0.52 across all sites combined). The correlation was strongest at the Tahorakuri site, but much weaker at both the Kaingaroa and Woodhill sites (Figure 5). Across the experiment as a whole, there were weak negative relationships between average ring width and both stress-wave velocity $(r=-0.29)$ (Figure 5) and outerwood density $(\mathrm{r}=-0.29)$ (Figure 6). The correlation between ring width and outerwood density
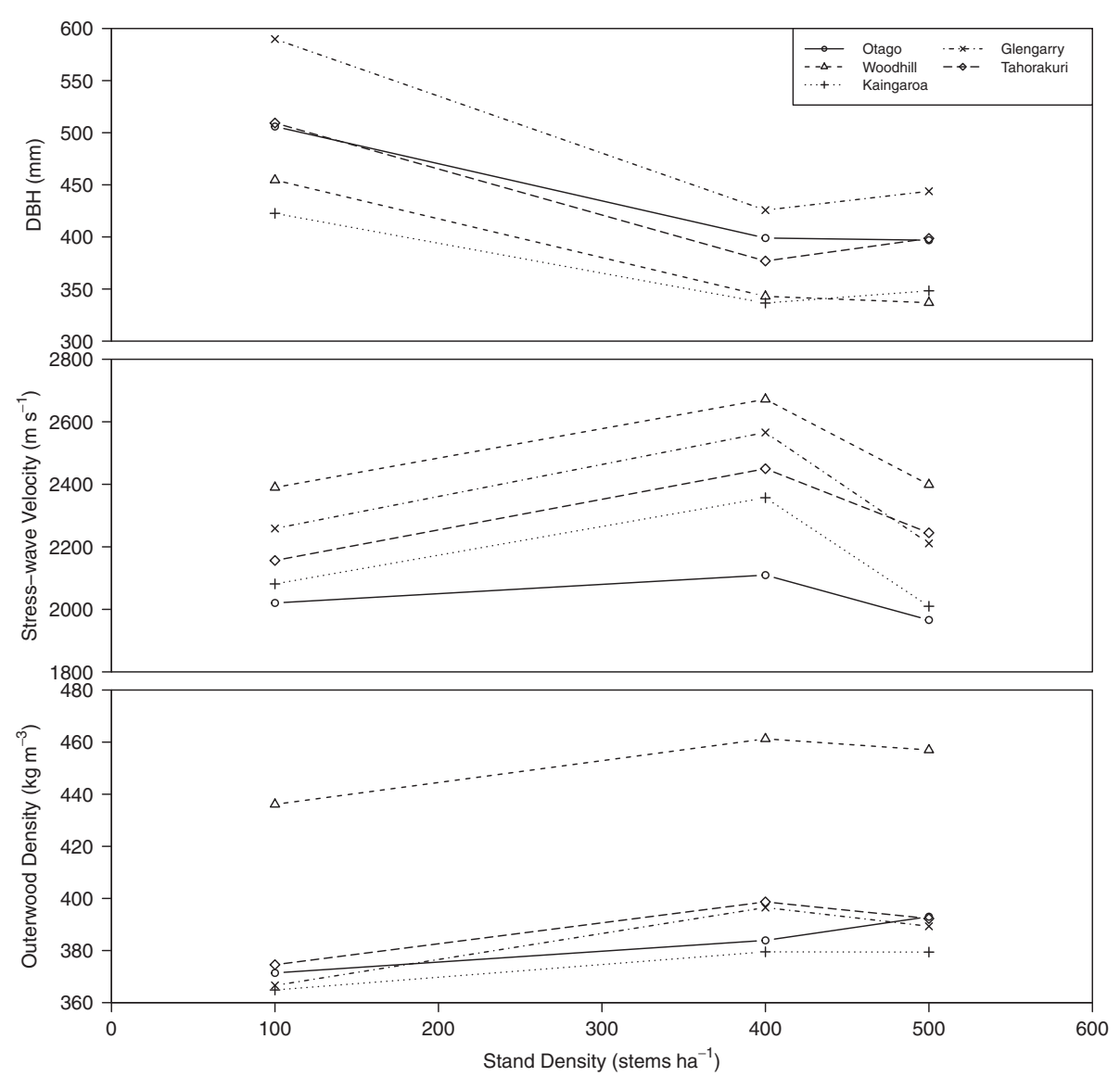

Figure 3 Variation in DBH, stress-wave velocity and outerwood density with stand density at each of the five sites. Data have been averaged across all seedlots and error bars have been omitted for clarity. 


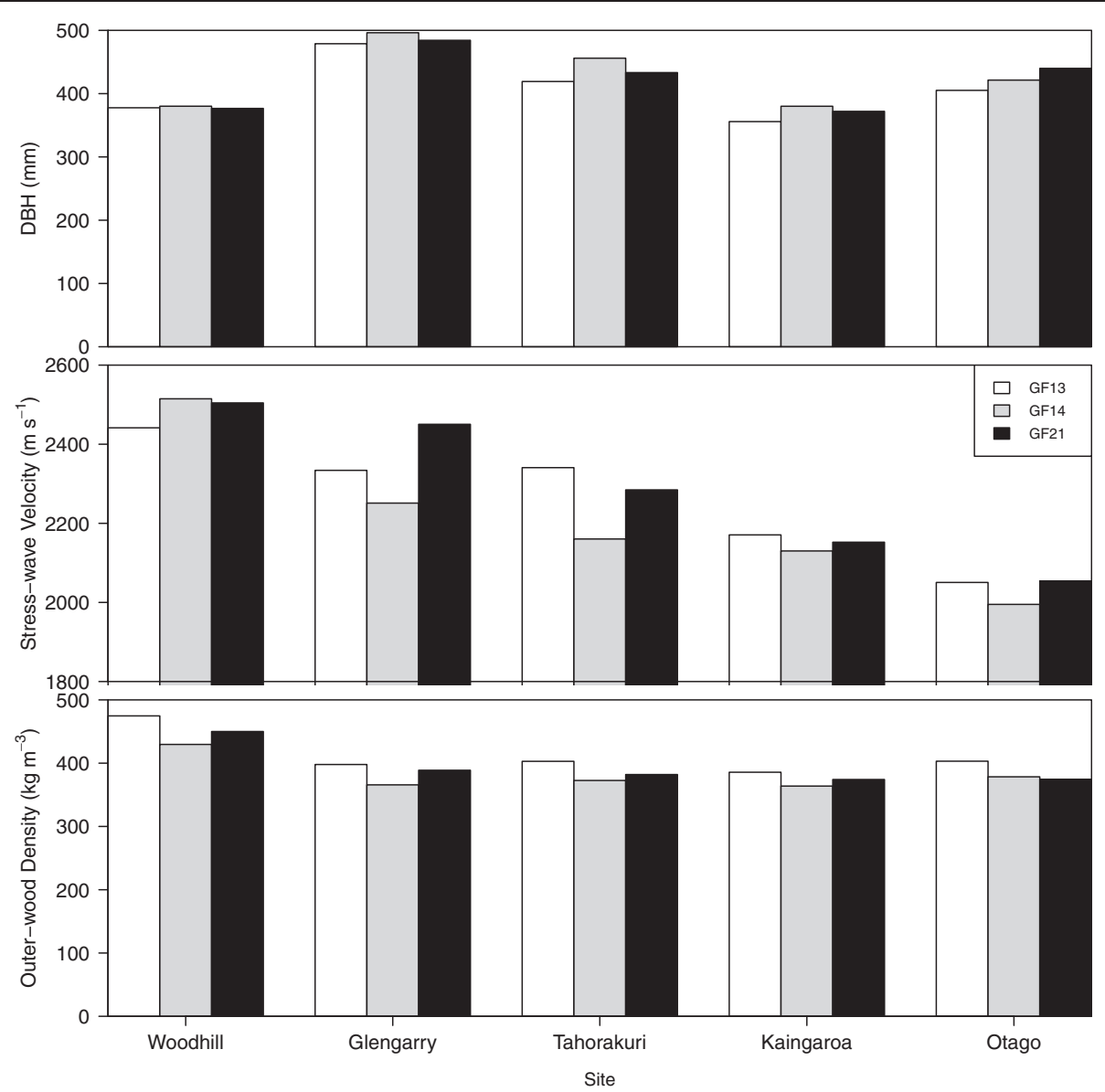

Figure 4 Mean values of DBH, stress-wave velocity and outerwood density by seedlot for each of the five sites. Data have been averaged across all levels of stand density.

appeared to be less pronounced in the 100 stems $^{-1} \mathrm{a}^{-1}$ treat-

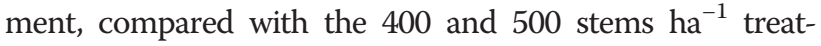
ments (Figure 6).

\section{Discussion}

Significant differences among sites, silvicultural regimes, and seedlots were observed for all growth and wood property traits assessed in this experiment. It should be remembered in all of the following discussion that wood properties were measured only in the lower stem where wood property responses to external influences tend to be at a maximum (Cown 1973, 1974). Across the experiment as a whole, both site and silviculture had the greatest effects on DBH and wood properties. Most of the results conformed to expectations, i.e. a reduction in wood density with latitude and elevation, driven by mean annual temperature (Palmer et al. 2013), and increasing outerwood density and stress-wave velocity in higher stocked stands. This increase in wood density and stress-wave velocity with increasing stand density has previously been reported in radiata pine (Grace and Evans 2012; Waghorn et al. 2007; Watt et al. 2011), but is in contrast to another study in young radiata pine which found no effect of stand density (across a range from 833 to 2500 stems ha $^{-1}$ ) on wood density (Lasserre et al. 2009).

For DBH and stress-wave velocity, the un-pruned, un-thinned 500 stems $\mathrm{ha}^{-1}$ treatment did not appear to conform to the trends observed with stand density. This same lack of fit to the trend was observed at all six sites when growth data initially collected eight years from planting were analysed (Carson et al. 1999b). Results from the current study indicate that stand density manipulation interacts with pruning to affect wood properties as similar values of outerwood density were observed in the 400 and 500 stems ha $^{-1}$ treatments. Previously, it has been suggested that pruning may increase wood density (Cown 1973; Gartner et al. 2003), in line with the concept of "crown-formed" wood (Amarasekara and Denne 2002; Gartner et al. 2002), whereby wood laid down within an active crown retains the characteristic properties of juvenile wood (i.e. wide growth rings, low wood density, high microfibril angle). It is clear that, apart from affecting intrinsic wood 


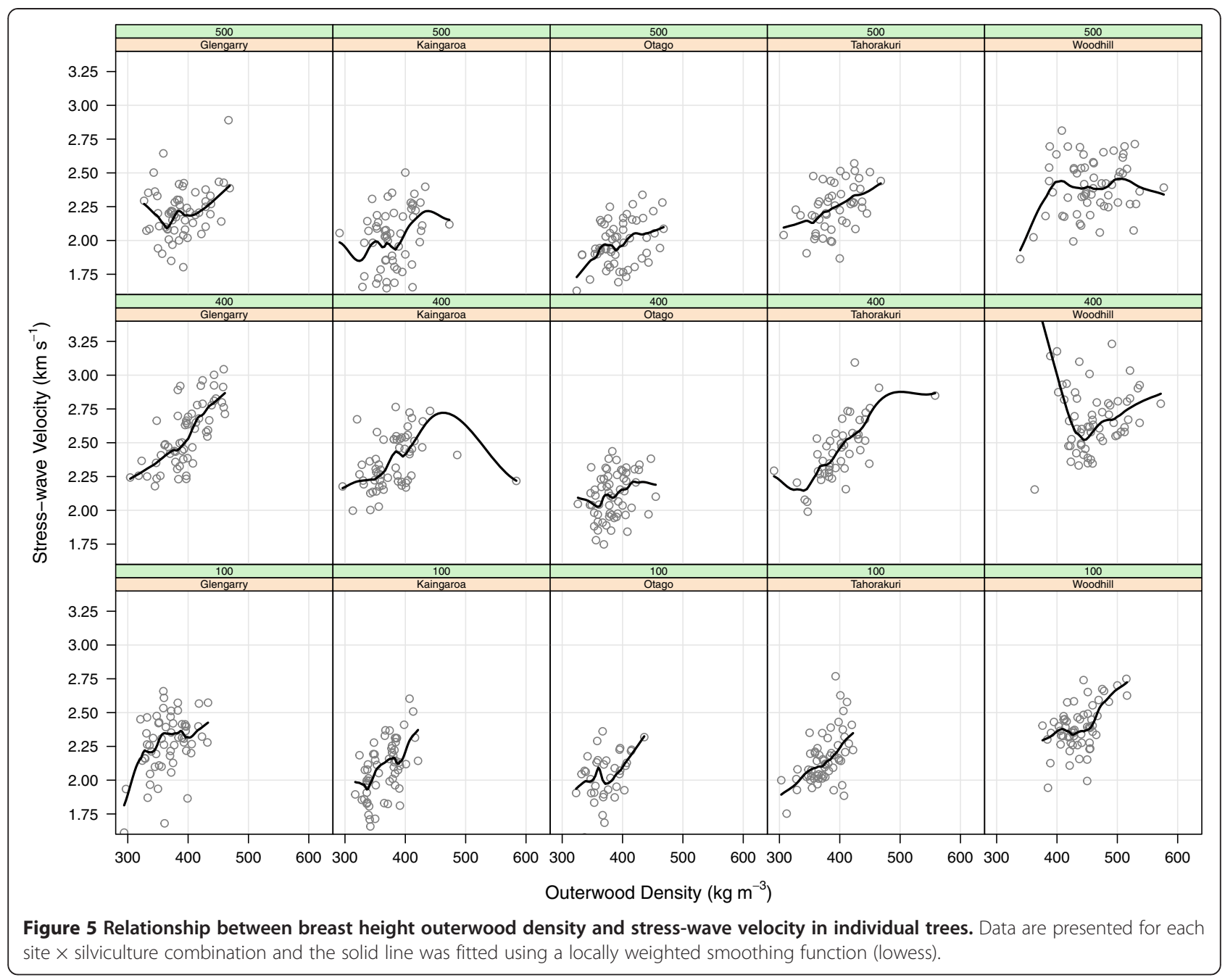

properties directly, factors that result in accelerated growth such as thinning or genetic improvement in particular could increase the actual volume of juvenile wood in stems (Cown 1974; Kennedy et al. 2013). This increase in the proportional size of the juvenile wood core is probably more significant for log utilisation than the quantitative changes to individual wood properties (Cown 1992).

The overall strong trend between stress-wave velocity (assumed to be only estimating the stiffness of the outerwood) and stand density implies a solid relationship between the latter and timber stiffness, in line with results from other studies (Lasserre et al. 2005; Watt et al. 2010). The current results, however, do not support the findings from another study in New Zealand (Grabianowski et al. 2004) or the results from a mature spacing study in Chile (Soto et al. 2012) which concluded that initial stand density $(2500,1667,833$ and 625 stems $\mathrm{ha}^{-1}$ across four sites) did not influence stress-wave velocity. This raises the possibility that site type may have an influence on silvicultural response. The apparently anomalous result for the un-pruned treatment also requires comment. While the outerwood density values showed a fairly clear trend with stand density, the un-pruned, un-thinned 500 stems ha $^{-1}$ treatment had consistently and significantly lower stress-wave velocity readings that were similar to the values in the 100 stems $\mathrm{ha}^{-1}$ treatment. Published studies to date suggest that the influence of branches on stress-wave velocity measurements should be insignificant, or at best minimal. For example, Lasserre et al. (2007) have indicated a 6-8 \% decrease in stress-wave velocity due to the presence of branches, which would assist in interpreting the results, but Auty and Achim (2008) have demonstrated little effect of branches on these readings. In the current study, a likely explanation is that the greater crown area has resulted in a higher proportion of "crown-formed" wood with lower basic wood density and higher moisture content (and hence, higher green density). Green density in combination with stresswave velocity is used to calculate longitudinal modulus 


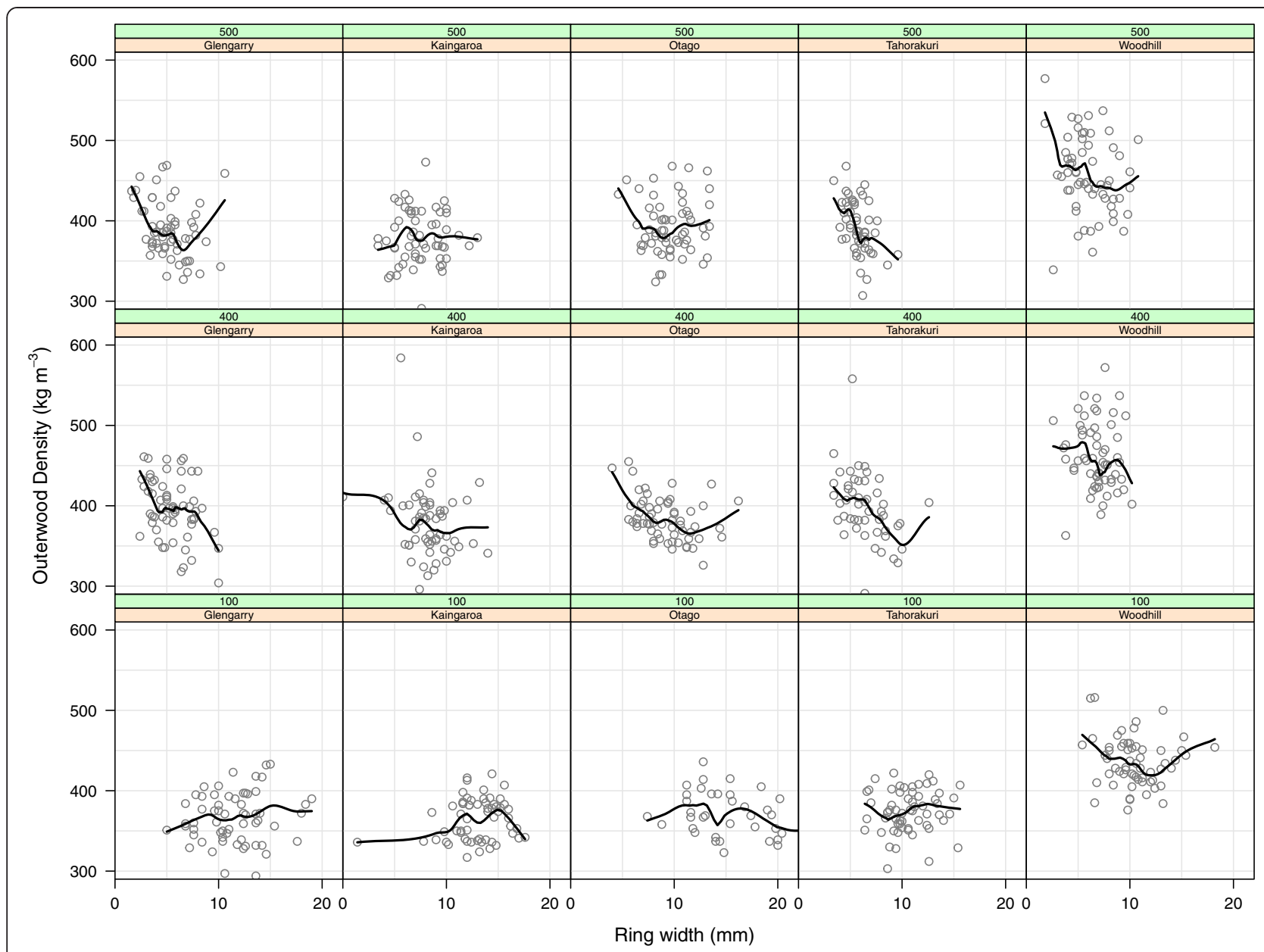

Figure 6 Relationship between the average width of the outer five rings and breast height outerwood density in individual trees. Data are presented for each site $\times$ silviculture combination and the solid line was fitted using a locally weighted smoothing function (lowess).

of elasticity. If green density is higher than the value of $1000 \mathrm{~kg} \mathrm{~m}^{-3}$ that is frequently assumed, then wood stiffness will be underestimated for a given stress-wave velocity (Wang 2013; Wang et al. 2001).

The original experiment on which the current study is based was designed to estimate site and silvicultural impacts on commercially available seedlots (to elicit realised genetic gain), rather than for comparison of seedlots per se. In general, these large-plot trials $(8 \times 8$ trees) have a low power for detecting seedlot differences, due to the large amount of site variance typically confounding genetic differences (Carson et al. 1999a). For ranking genotypes, breeders typically use single-tree-plot designs, in which genetic differences are detected with much greater precision, especially for traits like DBH that are highly influenced by the environment (Carson et al. 1999b). In addition, only a subset of plots and trees within these plots were sampled in the current study, which would have further reduced the power to detect differences between seedlots. Despite this, significant (although not highly so) differences were observed between the seedlots examined in this study for all the growth and wood quality traits that were assessed. Genetic differences have been repeatedly shown to be highly significant in single-tree progeny trials that breeders use for selection for $\mathrm{DBH}$, wood density, stress-wave velocity, and straightness (Dungey et al. 2009). The seedlots in this experiment were chosen to be genetically different in growth and straightness, but were not chosen to be genetically different in either wood density or stress-wave velocity. However, consistent and relatively large differences in density were noted, even with this less powerful design. In particular, the longinternode (LI28) GF13 seedlot consistently had the highest and the GF14 seedlot the lowest wood density. The GF14 seedlot also had the lowest stress-wave velocity, but the only significant difference was with the GF21 seedlot. Other studies comparing seedlots, families and/or clones confirm that there are large genetic differences in stresswave velocity (Chauhan et al. 2013; Lenz et al. 2013). 
Across the trial as a whole, there was a consistent but weak negative relationship between radial growth and stress-wave velocity. In previous radiata pine studies there are conflicting results, with some reporting a strong relationship (Lasserre et al. 2005; Watt et al. 2011) and others reporting no effect (Grabianowski et al. 2004; Soto et al. 2012). In this study there was no indication of a strong site effect on this relationship. On the other hand, many previous studies have proven a negative relationship between wood density and growth rate in conifers (e.g. Brazier 1970; Cown et al. 1991; Johansson 1993; Yang 1994; Zhang et al. 2002). The current study again confirmed a weak negative correlation for radiata pine across sites, treatments and seedlots, notwithstanding the possible existence of an associated negative genetic correlation, which could not be tested in this study. The difference in response between wood density and stresswave velocity (both related to wood stiffness) can be attributed to the fact that the two measures, while both taken at breast height, actually represent slightly different samples of the stem-wood. Outerwood increment cores are a biological sample incorporating the most recent five growth rings whereas stress-wave values represent a portion of the outer sapwood, approximately $50 \mathrm{~mm}$ in thickness (Paradis et al. 2013). These assessments are not necessarily sampling the same wood, particularly since the stress-wave value can be influenced by moisture content and the presence of reaction wood (Paradis and Murphy 2013).

\section{Conclusion}

In conclusion, results from this study support previous research which indicates that thinning, and to a lesser extent pruning, have a strong impact on DBH, stresswave velocity and outerwood density. Increasing stand density is consistently associated with stiffer and denser outerwood. Models for predicting wood properties, specifically stress-wave velocity and wood density, also require stand density to be taken into account. Ideally, seedlot information should also be included in predictive growth and wood quality models, as even with the limited data collected in the current study, the seedlots registered some significant effects. Both stress-wave velocity and wood density were found to be highly sensitive to site, silviculture and seedlot influences, and these traits could potentially be used together to identify material which has both high density and high stress-wave velocity.

The results presented here were obtained by sampling a subset of the treatments at five of the six sites in this experiment. The experiment is now reaching maturity and this presents an opportunity to undertake intensive measurements to determine the effects of the various treatment factors on both the wood properties of the trees and performance of the timber cut from them. This will provide important information to forest managers who are trying to maximise their financial returns by maximising the volume of fit-for-purpose timber they grow. Ideally, all treatment combinations should be sampled as they cover a wider range of stand densities and would also enable pruned and un-pruned stands growing at the same stand density to be compared.

\section{Competing interests}

SDC is a co-founder of Forest Genetics Ltd., a company that develops and sells elite radiata pine trees. However, none of the seedlots studied were produced by Forest Genetics Ltd. DJC, RBMcK and JRM declare that they have no competing interests.

\section{Authors' contributions}

SDC conceived the idea for the study, assisted with the data analysis and writing of the manuscript. DJC and RBMcK planned the wood quality assessment and the interpretation of the results. JRM assisted with the data analysis and writing of the manuscript. All authors read and approved the final version of the manuscript.

\section{Acknowledgments}

The 1987 silviculture-breeds experiment was designed by Dr Mike Carson, who also provided comments on an earlier version of the manuscript. The authors wish to acknowledge Wood Quality Initiative Ltd. who funded the original study and allowed publication of the results. Funding for publication of the results was also provided by Future Forests Research Ltd. Assistance with the field work was given by Pat Hodgkiss, John Lee and Dave Henley (Scion), and Jody Wharekura (contractor). Judy Hayes (Carson Associates) and Mark Kimberley (Scion) contributed to the statistical analyses. Bob Shula and three anonymous reviewers provided comments on an earlier version of the manuscript.

\section{Author details}

${ }^{1}$ Carson Associates Ltd., 34 Parawai Rd., Rotorua, New Zealand. ${ }^{2}$ Scion, Private Bag 3020, Rotorua, New Zealand.

Received: 23 April 2014 Accepted: 13 October 2014

Published online: 31 October 2014

\section{References}

Amarasekara, H, \& Denne, MP. (2002). Effects of crown size on wood characteristics of Corsican pine in relation to definitions of juvenile wood, crown formed wood and core wood. Forestry, 75(1), 51-61.

Apiolaza, LA, Chuahan, S, Hayes, M, Nakada, R, Sharma, M, \& Walker, J. (2013). Selection and breeding for wood quality: a new approach. New Zealand Journal of Forestry, 58(1), 32-37.

Auty, D, \& Achim, A. (2008). The relationship between standing tree acoustic assessment and timber quality in Scots pine and the practical implications for assessing timber quality from naturally regenerated stands. Forestry, 81(4), 475-487.

Brazier, JD. (1970). Timber improvement: II. The effect of vigour on young-growth Sitka spruce. Forestry, 43, 135-150.

Burdon, RD. (2010). Wood properties and genetic improvement of radiata pine. New Zealand Journal of Forestry, 55(2), 22-27.

Burdon, RD, \& Harris, JM. (1973). Wood density in radiata pine clones on four different sites. New Zealand Journal of Forestry Science, 3(3), 286-303.

Burdon, R, Walker, J, Megraw, B, Evans, R, \& Cown, D. (2004). Juvenile wood (sensu novo) in pine: conflicts and possible opportunities for growing, processing and utilisation. New Zealand Journal of Forestry, 49(3), 24-31.

Carson, SD, Garcia, O, \& Hayes, JD. (1999a). Realized gain and prediction of yield with genetically improved Pinus radiata in New Zealand. Forest Science, 45, 186-200.

Carson, SD, Kimberley, MO, Hayes, JD, \& Carson, MJ. (1999b). The effect of silviculture on genetic gain in growth of Pinus radiata at one-third rotation. Canadian Journal of Forest Research, 29(12), 1979-1984. doi:10.1139/x99-152.

Chauhan, SS, Sharma, M, Thomas, J, Apiolaza, LA, Collings, DA, \& Walker, JCF. (2013). Methods for the very early selection of Pinus radiata D. Don. for solid 
wood products. Annals of Forest Science, 70(4), 439-449. doi:10.1007/s13595-013-0270-3.

Cown, DJ. (1973). Effects of severe thinning and pruning treatments on the intrinsic wood properties of young radiata pine. New Zealand Journal of Forestry Science, 3(3), 379-389.

Cown, DJ. (1974). Comparison of the effects of two thinning regimes on some wood properties of radiata pine. New Zealand Journal of Forestry Science, 4 , 540-551.

Cown, DJ. (1992). Corewood (juvenile wood) in Pinus radiata - should we be concerned? New Zealand Journal of Forestry Science, 22(1), 87-95.

Cown, DJ, \& McConchie, DL. (1983). Radiata Pine Wood Properties Survey (1979 to 1982). FRI Bulletin 50. Rotorua, New Zealand: New Zealand Forest Service, Forest Research Institute.

Cown, DJ, McConchie, DL, \& Young, GD. (1991). Radiata Pine Wood Properties Survey. FRI Bulletin 50. Rotorua: Ministry of Forestry, Forest Research Institute.

Cown, DJ, McKinley, RB, \& Ball, RD. (2002). Wood density variation in 10 mature Pinus radiata clones. New Zealand Journal of Forestry Science, 32(1), 48-69.

Downes, G, \& Drew, DM. (2008). Climate and growth influences on wood formation and utilisation. Southern Forests, 70(2), 155-167.

Dungey, HS, Brawner, JT, Burger, F, Carson, M, Henson, M, Jefferson, P, \& Matheson, AC. (2009). A new breeding strategy for Pinus radiata in New Zealand and New South Wales. Silvae Genetica, 58(1-2), 28-38.

Gartner, BL, North, EM, Johnson, GR, \& Singleton, R. (2002). Effects of live crown on vertical patterns of wood density and growth in Douglas-fir. Canadian Journal of Forest Research, 32, 439-447. doi:10.1139/x01-218.

Gartner, B, Robbins, JM, \& Newton, M. (2003). Effects of pruning on wood density and tracheid length in young Douglas-fir. Wood and Fiber Science, 37(2), 304-313.

Grabianowski, M, Manley, B, \& Walker, J. (2004). Impact of stocking and exposure on outerwood acoustic properties of Pinus radiata in Eyrewell forest. New Zealand Journal of Forestry, 49(2), 13-17.

Grace, JC, \& Evans, R. (2012). Impact of thinning and pruning on selected wood properties in individual radiata pine trees in New Zealand. New Zealand Journal of Forestry Science, 42, 117-129.

Jayawickrama, KJS, \& Carson, MJ. (2000). A breeding strategy for the New Zealand radiata pine breeding cooperative. Silvae Genetica, 49(2), 82-90.

Johansson, K. (1993). Influence of initial spacing and tree class on the basic density of Picea abies. Scandanavian Journal of Forest Research, 8, 18-27.

Kennedy, SG, Cameron, AD, \& Lee, SJ. (2013). Genetic relationships between wood quality traits and diameter growth of juvenile core wood in Sitka spruce. Canadian Journal of Forest Research, 43(1), 1-6.

Kumar, S, \& Burdon, RD. (2010). Genetic improvement of stiffness of radiata pine: synthesis of results from acoustic assessments. New Zealand Journal of Forestry Science, 40, 185-197.

Larson, PR. (1969). Wood Formation and the Concept of Wood Quality. Yale University School of Forestry Bulletin No. 74 (p. 54).

Lasserre, J-P, Mason, EG, \& Watt, MS. (2005). The effects of genotype and spacing on Pinus radiata [D. Don] corewood stiffness in an 11-year old experiment. Forest Ecology and Management, 205(1-3), 375-383. doi:10.1016/j.foreco.2004.10.037.

Lasserre, JP, Mason, EG, \& Watt, MS. (2007). Assessing corewood acoustic velocity and modulus of elasticity with two impact based instruments in 11-year-old trees from a clonal-spacing experiment of Pinus radiata D. Don. Forest Ecology and Management, 239(1-3), 217-221.

Lasserre, JP, Mason, EG, Watt, MS, \& Moore, JR. (2009). Influence of initial planting spacing and genotype on microfibril angle, wood density, fibre properties and modulus of elasticity in Pinus radiata D. Don corewood. Forest Ecology and Management, 258(9), 1924-1931. doi:10.1016/j.foreco.2009.07.028.

Lenz, P, Auty, D, Achim, A, Beaulieu, J, \& Mackay, J. (2013). Genetic improvement of white spruce mechanical wood traits_early screening by means of acoustic velocity. Forests, 4(3), 575-594. doi:10.3390/f4030575.

Ministry for Primary Industries. (2013). National Exotic Forest Description as at 1 April 2013. Wellington: Ministry for Primary Industries.

Palmer, DJ, Kimberley, MO, Cown, DJ, \& McKinley, RB. (2013). Assessing prediction accuracy in a regression kriging surface of Pinus radiata outerwood density across New Zealand. Forest Ecology and Management, 308, 9-16.

Paradis, N, \& Murphy, GE. (2013). Effects of curvature in hybrid poplar on acoustic velocity at the tree level. New Zealand Journal of Forestry Science, 43(1), 7. doi:10.1186/1179-5395-43-7.

Paradis, N, Auty, D, Carter, P, \& Achim, A. (2013). Using a standing-tree acoustic tool to identify forest stands for the production of mechanically-graded lumber. Sensors (Basel), 13(3), 3394-3408. doi:10.3390/s130303394.
Ross, RJ, \& Pellerin, RF. (1988). NDE of wood-based composites with longitudinal stress waves. Forest Products Journal, 38(5), 39-45.

Smith, DM. (1954). Maximum moisture content method for determining specific gravity of small wood samples. (Report 2014). Madison, WI: United States Department of Agriculture, Forest Service, Forest Products Laboratory.

Soto, L, Valenzuela, L, \& Lasserre, JP. (2012). Effect of initial planting density in dynamic modulus of elasticity in standing trees and logs of 28 years old radiata pine plantation in sandy soil, Chile. Maderas. Ciencia y Tecnología, 14 (2), 209-220. doi:10.4067/S0718-221X2012000200008.

Waghorn, MJ, Watt, MS, \& Mason, EG. (2007). Influence of tree morphology, genetics, and initial stand density on outerwood modulus of elasticity of 17-year-old Pinus radiata. Forest Ecology and Management, 244(1-3), 86-92. doi:10.1016/j.foreco.2007.03.057.

Wang, X. (2013). Acoustic measurements on trees and logs: a review and analysis. Wood Science and Technology, 47(5), 965-975. doi:10.1007/s00226-013-0552-9.

Wang, X, Ross, RJ, McClennan, M, Barbour, RJ, Erickson, JR, Forsman, JW, \& McGinnis, GD. (2001). Non-destructive evaluation of standing trees with stress wave methods. Wood and Fiber Science, 33, 522-533.

Watt, MS, Sorensson, C, Cown, DJ, Dungey, HS, \& Evans, R. (2010). Determining the main and interactive effect of age and clone on wood density, microfibril angle, and modulus of elasticity for Pinus radiata. Canadian Journal of Forest Research, 40(8), 1550-1557. doi:10.1139/x10-095.

Watt, MS, Zoric, B, Kimberley, MO, \& Harrington, J. (2011). Influence of stocking on radial and longitudinal variation in modulus of elasticity, microfibril angle, and density in a 24-year-old Pinus radiata thinning trial. Canadian Journal of Forest Research, 41(7), 1422-1431. doi:10.1139/x11-070.

Yang, K-C. (1994). Impact of spacing on width and basal area of juvenile and mature wood in Picea mariana and Picea glauca. Wood and Fiber Science, 26(4), 479-488.

Zhang, SY, Chauret, G, Ren, QH, \& Desjardins, R. (2002). Impact of initial spacing on plantation black spruce lumber grade yield, bending properties, and MSR yield. Wood and Fiber Science, 34(4), 460-475.

Zobel, BJ, \& Sprague, JR. (1998). Juvenile Wood in Forest Trees. Berlin: Springer.

\section{doi:10.1186/s40490-014-0026-3}

Cite this article as: Carson et al:: Effects of site, silviculture and seedlot on wood density and estimated wood stiffness in radiata pine at mid-rotation. New Zealand Journal of Forestry Science 2014 44:26.

\section{Submit your manuscript to a SpringerOpen ${ }^{\circ}$ journal and benefit from:}

- Convenient online submission

- Rigorous peer review

- Immediate publication on acceptance

- Open access: articles freely available online

- High visibility within the field

- Retaining the copyright to your article

Submit your next manuscript at springeropen.com 